\title{
Salpingopharyngeus fistula by means of videosurgery to treat horse bilateral gutural pouch chronic empyema - a case study
}

\author{
Fístula salpingofaríngea por videocirurgia para tratamento de empiema \\ crônico de bolsa gutural bilateral em equino - relato de caso
}

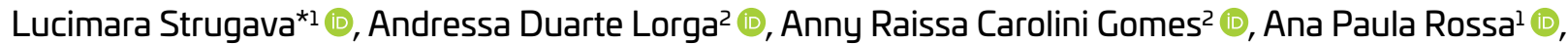 \\ Jéssica do Rocio Janiszewski ${ }^{1}$, , Peterson Triches Dornbusch ${ }^{3}$ (i)
}

\begin{abstract}
The aim of this paper is to report the Salpingopharyngeus fistula technique by means of videosurgery through a natural orifice (NOTES) in order to treat bilateral empyema. A mare was seen at the Large Animal Sector of UFPR, with a history of bilateral purulent nasal discharge associated with dysphagia lasting for ninety days. The animal was submitted to endoscopy, showing a moderate amount of purulent secretion in both guttural pouches. With no improvement on the clinical treatment, we opted for surgical treatment by endoscopy through Salpingopharyngeus fistula made with the aid of a device containing an electrical scalpel developed to perform this technique. It consisted of making an incision in the pharyngeal recess in order to access the guttural pouches and subsequently drain the purulent content. The patient was discharged at the same day and returned to work 30 days after the procedure. Surgical treatment for cases of guttural pouch empyema is indicated when the clinical resolution has not been effective, and the minimally invasive technique is indicated due to the reduction of risks and the easiness of postoperative management. Until this moment, there are no reports of the salpingopharyngeal fistula technique through video surgery for the treatment of guttural pouch empyema, which has proved to be efficient for the treatment of the disease.
\end{abstract}

KEYWORDS: endoscopy; horses; treatment; Streptococcus Equi

RESUMO: O objetivo deste trabalho é relatar a técnica de fístula salpingofaríngea por videocirurgia através de orifício natural (NOTES) para tratamento de empiema bilateral. Uma égua foi atendida no Setor de Grandes Animais da UFPR, com histórico de secreção nasal purulenta bilateral associado a disfagia há noventa dias. $\mathrm{O}$ animal foi submetido à endoscopia, evidenciando moderada quantidade de secreção purulenta em ambas as bolsas guturais. Sem apresentar melhora com o tratamento clínico, optou-se pelo tratamento cirúrgico por endoscopia através da realização de uma fístula salpingofaríngea feita com o auxílio de um dispositivo contendo eletrobisturi, desenvolvido para a realização desta técnica; que consistiu na realização de uma incisão no recesso faríngeo, para o acesso das bolsas guturais e posterior drenagem do conteúdo purulento. $\mathrm{O}$ paciente recebeu alta médica no mesmo dia e retornou ao trabalho 30 dias após o procedimento. $\mathrm{O}$ tratamento cirúrgico para os casos de empiema de bolsa gutural é indicado quando a resolução clínica não foi efetiva, sendo a técnica minimamente invasiva indicada devido à redução de riscos e à facilidade do manejo pós-operatório. Até o momento, não há relatos da técnica de fístula salpingofaríngea através de videocirurgia para o tratamento de empiema de bolsa gutural, a qual mostrou-se eficiente para o tratamento da enfermidade.

PALAVRAS-CHAVE: endoscopia; cavalos; tratamento; Streptococcus Equi

\section{INTRODUCTION}

Guttural pouches are diverticula from the auditory tube, which connect the nasopharynx to the middle ear; each guttural pouch of an adult horse has a volume of approximately $300 \mathrm{ml}$ (FREEMAN; HARDY, 2012). These structures occupy a wide area in the caudal portion of the head, extending from the pharyngeal roof to the beginning of the esophagus, with each pouch divided into a lateral and medial compartment by the hyoid style bone. They are dorsally bounded by the base of the skull and by the first cervical vertebra, ventrally by the retropharyngeal lymph nodes and the pharynx. Laterally, the diverticula are bordered by the pterygoid and palatine muscles, by the vertical branch of the mandibular and temporomandibular joint, by the occipitomandibular part of the digastric muscle and the mandibular and parotid glands. (BARAKZAI, 2007).

The function of the guttural pouch is still under debate among clinicians, but among the possible functions described

\footnotetext{
'Resident Veterinarian of Medical and Surgical Clinic of Large Animals at the Federal University of Paraná

2Graduate student, Federal University of Paraná - Curitiba PR

${ }^{3}$ Teacher in the Department Medicine of Veterinary, Federal University of Paraná - Curitiba PR

*Corresponding author: lucimarastrugava@gmail.com

Received: 10/03/2020. Accepted: 12/11/2020
} 
in the literature are: equalizing the air pressure on both sides of the tympanic membrane, involvement in the mechanism of heating the inspired air, cooling the brain, regulation of cerebral blood pressure, vocalization and serve as a bed of pharyngeal mucosa (THOMASSIAN et al., 2001; JUKIC et al., 2019).

Empyema is the accumulation of unilateral or bilateral purulent material, and is usually associated with infection by Streptococcus equi, being frequently associated with a garrotillo episode, where $7 \%$ of horses with this condition develop empyema (FILHO et al., 2008).

Treatment of empyema can have a clinical or surgical approach. The surgical approaches described in the literature are mainly by open technique, the most used for accessing the Viborg triangle. One of the disadvantages of this method is the increased risk of nerve damage due to nearby structures, such as: common carotid artery, internal and external carotid artery, maxillary artery, cervical cranial ganglion, cervical sympathetic trunk, retropharyngeal lymph node, glossopharyngeal nerve (IX), vagus (X), accessory (XI), hypoglossal (XII), pharyngeal branch of the vagus nerve $(\mathrm{X})$, cranial laryngeal nerve and jaw (TEIXEIRA, 2019). The video-assisted surgeries in these cases aim to facilitate the solution to the problem, providing faster return to sports activities through the healing process as they are less invasive. Unlike traditional surgical techniques, video surgeries provide less access and manipulation with less invasion, in addition to maintaining adjacent structures preserved (CRAMP, PRANGE, NICKELS, 2014; GEHLEN, 2005).

The technique of opening a salpingopharyngeal fistula by video surgery employed in this animal for the treatment of guttural pouch empyema is not described in the literature, being a modification of the technique developed by Koch et al. (2018), which used ten corpses of horses, for pharyngeal opening of the guttural pouch with laser. Moreover, after that, employing computed tomography to analyze the diameter and aspect of the formed fistula. As this is a cadaveric study, the post-surgical evolution could not be evaluated. Therefore, the aim of this paper is to report the first case in the literature employing a salpingopharyngeal fistula by natural orifice video surgery (NOTES), for the treatment of guttural pouch empyema in horses using a device developed specifically for this purpose.

\section{CASE REPORT}

A six-year-old mixed breed mare, weighing $264 \mathrm{~kg}$, with a history of having purulent bilateral nasal discharge for approximately one year, was referred to the UFPR Large Animal Sector for endoscopic examination of the airways.

In the anamnesis, the owner reported the occurrence of dysphagia for sixty days, dyspnea and progressive weight loss. The only alteration found on physical examination was in pulmonary auscultation, where there was a pulmonary crepitation in the right antimere in the caudal lobe.
The animal was intravenously sedated with detomidine $(0.02 \mathrm{mg} / \mathrm{kg})$ (Detomidin ${ }^{\oplus 5}$ Syntec do Brasil LTDA, Santana de Parnaíba, Brasil), for endoscopy of the airways. During the examination, a moderate amount of purulent secretion was observed inside the guttural pouches, indicating that this was a case of empyema of the guttural pouch, the dysphagia being justified by the involvement of the nerves located there. Surgical treatment was indicated, but the procedure was not authorized by the owner. So the animal was subjected to intramuscular antibiotic therapy with ceftioufur $(4.4 \mathrm{mg} /$ kg) (Cef 50 Agener União Saúde Animal, São Paulo, Brazil), once a day for 10 days, associated with dexamethasone $(0.1$ $\mathrm{mg} / \mathrm{kg}$ ) (Dexaflan - Vilavet Saúde Animal LTDA, São José dos Pinhais, Brazil) intravenously for three days.

Three months after the consultation, the animal returned to the hospital for surgical treatment, since several attempts at clinical treatment were made and the patient was extremely cachectic due to the difficulty in feeding. There was also an abscess (Figure 1 A) in the region of the left pouch, since $200 \mathrm{ml}$ of purulent content was removed from the property by using a needle and syringe.

On physical examination, the temperature was $38.7^{\circ} \mathrm{C}$, pulmonary crepitation persisted in both antimers and there was an increase in bilateral volume in the region of the Viborg triangle with the presence of an abscess on the left side perceived through palpation, with the other physical parameters being regular.

To perform video surgery, the animal was kept in contention trunk for species and sedated with detomidine (0.02 $\mathrm{mg} / \mathrm{kg}$ ); during the procedure, sedation was maintained with the same drug in continuous infusion (at rates of 1 to $10 \mu \mathrm{g}$ $/ \mathrm{kg}$ ). For local anesthesia and analgesia $10 \mathrm{ml} 2 \%$ lidocaine (Lidovet - Laboratório Bravet LTDA, Rio de Janeiro, Brazil) was employed in each nostril and $20 \mathrm{ml} \mathrm{10 \%} \mathrm{lidocaine} \mathrm{(Xylestesin}$ - Cristália Produtos Químicos Farmacêuticos LTDA, Itapira, Brazil) without vasoconstrictor, instilled directly into the pharyngeal recess, the site of the pharyngeal incision to access the guttural pouches.

The endoscope was directed through the right nostril to the ventral meatus to the nasopharyngeal region, proceeding
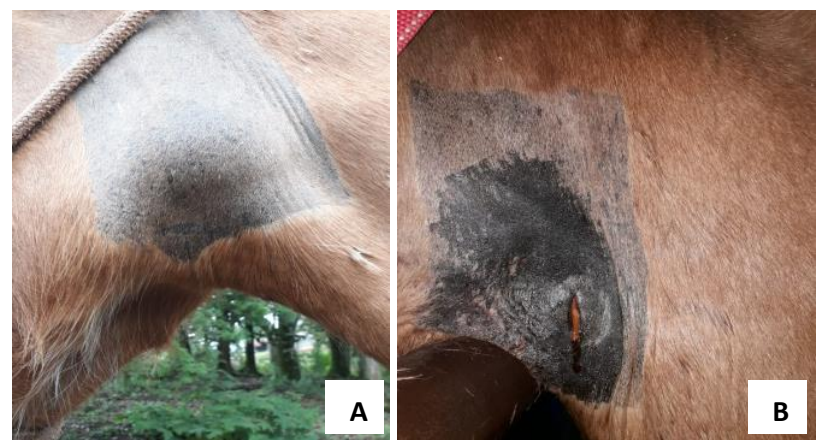

Source: Personal archive, 2019

Figure 1. Left Viborg triangle region with increased volume showing the presence of abscess $(A)$ and abscess after drainage (B). 
to the entrance of the guttural pouch. A tubular metallic device with approximately $60 \mathrm{~cm}$, with the tapered tip, covered by a plastic sheath, developed for this purpose(Figure $2 \mathrm{~A}$ and B) was inserted in the contralateral nostril, isolating the device and assuring that only the tip would have the function of an electric scalpel. The base of this device was attached and adapted for use with monopolar electro cautery. During its introduction, it was protected by a retractable silicone sheath in order not to cause lesions on the mucosa of the nasal cavity. After being positioned, an incision of approximately eight centimeters was made in the pharyngeal recess in order to access both guttural pouches, to drain the content on both sides. After the procedure, it was possible to enter the endoscope in both pouches through the salpingopharyngeal fistula. (Figure 3).

The five-centimeter abscess present in the region of the left Viborg triangle was drained (figure 1B) after the surgical procedure; for this, one performed trichotomy followed by antisepsis with iododegermante (Riodeine, Indústria Farmacêutica Rioquímica LTDA, São José do Rio Preto, Brazil), iodotopic (Riodeine, Indústria Farmacêutica Rioquímica LTDA, São José do Rio Preto, Brazil) and iodized alcohol (Riodeine, Indústria Farmacêutica Rioquímica LTDA, São José do Rio Preto, Brazil), followed by blocking with $2 \%$ lidocaine and skin, subcutaneous incision and abscess capsule. After drainage, it was washed with hydrogen peroxide (Hydrogen peroxide 10, Indústria Farmacêutica Rioquímica LTDA, São José do Rio Preto, Brazil) and topical iodine.

In the post-surgical period, the animal was submitted to systemic intramuscular antibiotic therapy with benzathine penicillin (20,000 IU / Kg, Megacilin Super Plus, Agener União, União Química Química Nacional S / A, São Paulo, Brazil) totaling three applications with 48 hours between each of them, intramuscular flunixin meglunine, $(1.1 \mathrm{mg} / \mathrm{kg}$ ) (Vetecia Lab. De Produtos Veterinário LTDA, Jacareí, Brazil) once a day for three days, and oral Omeprazole $(2 \mathrm{mg} / \mathrm{kg}$, Omeprazole
Pellets $8.5 \%$, Drogavet ${ }^{\oplus}$ - Veterinary Manipulation Pharmacy, Curitiba, Brazil) once a day for three days.

The animal was discharged on the same day, with recommendations for administering the prescribed drugs and cleaning the abscess wound, until complete healing. After 30 days, the animal showed improvement in its general condition, and absence of nasal discharge, demonstrating the healing of the disease, recovering a good part of its body score, without signs of dysphagia, or any post-surgical complications resulting from the technique used. Due to the impossibility of transporting the animal to the hospital, a new image exam was not performed. However, by telephone contact six months after the procedure, the owner reported complete recovery of the animal without the recurrence of any type of nasal discharge or any other clinical signs.

\section{DISCUSSION}

Guttural pouch empyema, with or without chondroid formation, may be difficult to heal with conventional medical treatment in some horses (GEHLEN; OHNESORGE, 2005). The bases of treatment are the removal of purulent material, the eradication of infections, the reduction of inflammation,

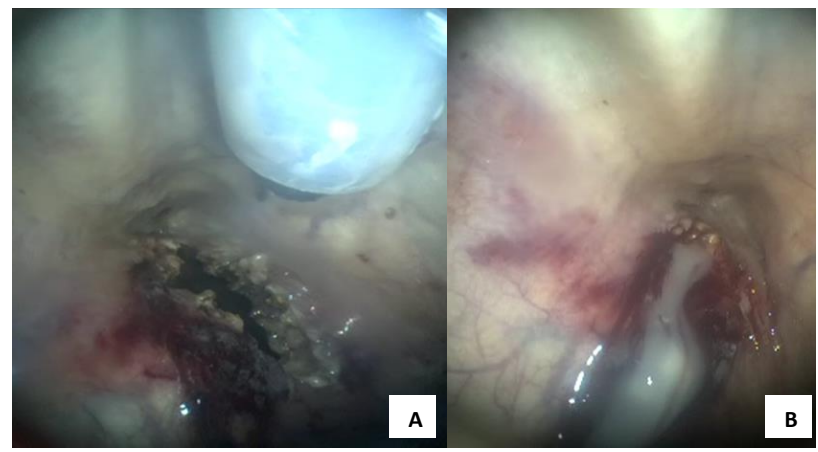

Source: Personal archive

Figure 3. Salpingopharyngeal fistula. A: fistula right after its creation. B: drainage of purulent secretion through the fistula

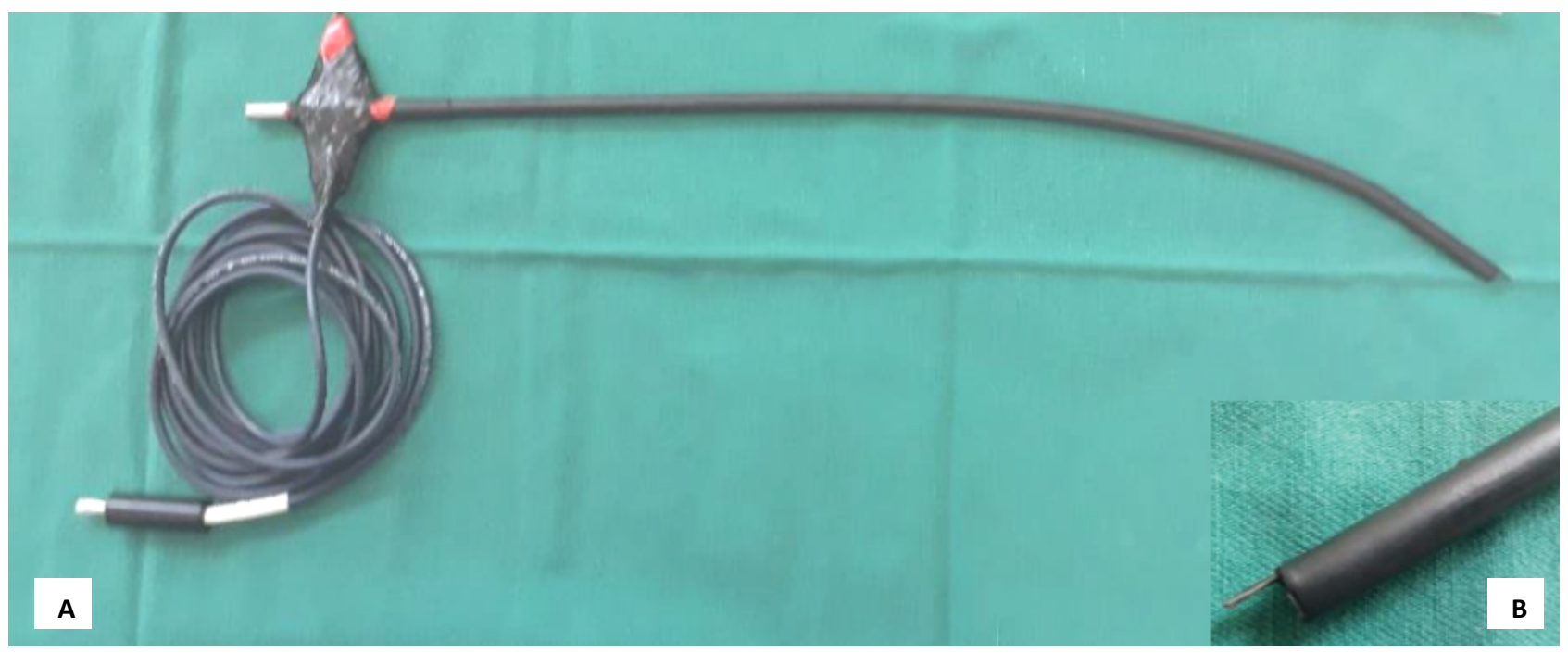

Source: Personal archive .

Figure 2. A-Cauterization device used to perform the fistula. B: detail of the metallic and tapered tip of the device. 
the relief of respiratory distress and the provision of nutritional support for severely affected animals (EDWARDS; SANTSCHI, 2002; RADOSTITS et al., 2006). Surgical treatment for guttural pouch empyema is indicated in cases not responsive to clinical treatment, when chondroid formation occurs or when the purulent material becomes thickened (TURNER; McILWRAITH, 2002), as in this case.

Minimally invasive surgery for the healing of guttural pouch empyema has several advantages, such as the minimal approach, with the use of light sedation with no need for general anesthesia, reduced risk of iatrogenic injury to the cranial nerve, and easy post-surgery management; as the surgical wound is internal and has no communication with the external environment, it minimizes the possibility of an ascending infection (KOCH et al., 2018). The animal in this report was subjected to sedation only, was discharged on the same day of the procedure and had no post-surgical complications.

In a case reported by Schambourg; Marcoux; Céleste (2006), a right salpingopharyngeal fistula and fenestration of the median septum were performed in both guttural pouches with laser, for treatment of guttural tympanism. To perform the procedure, the foal was kept in a standing position and there were no complications, however, there was a recurrence one month after the surgery, with complete closure of the mid septal fenestration. The animal presented recurrence of tympanism and developed guttural pouch empyema, thus, it was again submitted to another minimally invasive procedure, under general anesthesia, with access through the Viborg triangle, however. Three skin incisions were made for the introduction of cannulas and trocars. The median septum was dissected, allowing the creation of a fenestration, and a $5 \mathrm{~mm}$ fragment was resected in each pouch to allow content drainage. Skin incisions were treated for second intention to allow material to drain in the postoperative period. After one month, the patient had bilateral nasal discharge; endoscopy showed mild bilateral empyema, which was resolved only by washing the pouch with saline solution. The surgical access region is similar to the one used in the present report, however, in this case there was no recurrence, which may have occurred due to the use of an electric scalpel. This shows that the fistula performed was sufficient to drain the entire contents of the empyema and remained open for post-procedure drainage.
According to Watkins \& Parente (2018), the use of lasers for the creation of salpingopharyngeal fistula was previously described for the treatment of guttural pouch mycosis. In this study, a laser was used in order to create a salpingopharyngeal fistula in seven horses with guttural pouch mycosis. In these animals, the pharyngeal recess in the dorsal portion of the affected pouch was incised, forming a $1.5 \mathrm{~cm}$ fistula. In four animals, through this incision, the pouch was reached by applying the laser directly to the ringworm plates. It has been shown that opening the salpingopharyngeal fistula also facilitates access for debridement of fungal plaques that are not closely associated with the vasculature or nerves and for dissecting the plaque with the laser. In two animals, the fistula closed two months after the surgical procedure and a Foley tube was not used to maintain the opening of the fistula. In the reported patient, the fistula of approximately eight $\mathrm{cm}$ was formed with the use of an electrical scalpel and remained open for drainage of the contents of the empyema, being the first case in the literature with the use of an electrical scalpel for the treatment of guttural pouch empyema.

Teixeira et al. (2019) conducted a study on five healthy animals for performing salpingopharyngeal fistula through video surgery. For this study, a monopolar cauterization device was created to perform fenestration between the pharyngeal recess and the larynx. The formed fistulas were followed weekly by endoscopy, until completing 35 days after surgery. Through endoscopic monitoring, it was found that the closer to the pharyngeal recess, the lower are the chances of a closure. The developed device allowed a fast and easy procedure, with low cost, and can be attached to any monopolar cautery. This study corroborates the treatment performed on the animal in this report, showing the clinical efficiency of the salpingopharyngostomy technique, and the electrical scalpel employed in the animal in this report is similar to the mentioned study .

\section{CONCLUSION}

The opening of a salpingopharyngeal fistula by video-surgery with an adapted electrical scalpel proved to be highly effective in this case, having as advantages the need for only light sedation to perform the procedure in a standing position, fast recovery and easy post-operative management, allowing the patient to recover.

\section{REFERENCES}

BARAKZAI, S. Handbook of equine respiratory endoscopy. l.ed. Philadelphia: Elsevier Saunders, 2007. 127 p.

CRAMP, P. A.; PRANCE, T.; NICKELS, F. A. Standing equine Surgery of the upper respiratory tract. Veterinary Clinics of North America: Equine Practice. v. 30, n. 1, p.1ll-141, 2014.
EDWARDS, R.B.; SANTSCHI, E.M. Diagnosis and treatment of upper airway disorders in the foal. In: ANNUAL VETERINARY SYMPOSIUM ACVS (AMERICAN COLLEGE OF VETERINARY SURGEONS), 12., 2002, San Diego, EUA. Anais... Betheseda: American College of Veterinary Surgeons, 2002. p.213-216. 
FILHO, D.Z. et al. Empiema de bolsa gutural. Revista Científica Eletrônica de Medicina Veterinária. Ano VI, n 10. 2008

FREEMAN, D.E.; HARDY, J. Guttural Pouch. In: AUER, J.A.; STICK, J.A. Equine surgery. 4 ed. Saint Louis: Elsevier, 2012. cap. 46, p. 623-642.

FREEMAN, D.E. Complications of surgery for diseases of the guttural pouch. Veterinary Clinics of North America - Equine Practice, v. 24, n. 3, p. 485-497, 2008.

GEHLEN, H.; OHNESORGE, B. Laser Fenestration of the Mesial Septum for Treatment of Guttural Pouch Chondroids in a Pony. Veterinary Surgery, v. 34, n. 1, p. 383-386, 2005.

JUKIC, C.C. et al. Evaluation of the effect of laser salpingopharyngostomy on the guttural pouch environment in horses Chantelle. Equine Veterinary Journal. v.0.n.0, p.l-8, 2019

$\mathrm{KOCH}$, D.W. et al. Comparison of two techniques for transpharyngeal endoscopic auditory tube diverticulotomy in the horse. Journal of Veterinary Science, v.19, n.6, p. 835-839, 2018.

RADOSTITIS, O.M. et al. Veterinary Medicine: A textbook of the diseases of cattle, sheepe, goats, pigs and horses. 10 th. ed. Philadelphia: Saunders Elsevier, 2006. 2065 p.
SMITH, B. P. Large animal internal medicine. 4.ed. Missouri: Elsevier, 2009. 1872 p

SCHAMBOURG, M.A.; MARCOUX, M.; CÉLESTE, C. Salpingoscopy for the treatment of recurrent guttural pouch tympany in a filly - case report. Equine Veterinary Education, v.18, n.5, p. 231-237, 2006.

TEIXEIRA, W.T. Fístula salpingofaríngea por videocirurgia para tratamento de empiemas guturais crônicos em eqüinos. 2019.50 f. Dissertação (Mestrado em Ciências Veterinárias) - Universidade Federal do Paraná, Curitiba, 2019.

THOMASSIAN, A. et al. Avaliação dos processos de cicatrização da fenestração do septo-medial da bolsa gutural em eqüinos. Revista educação continuada, v. 4, n. 1, p. 08-18, 2001.

THOMASSIAN, A. Enfermidades dos Cavalos. 4.ed. São Paulo, SP: Livraria Varela, 2005. 574 P

TURNER, A. S.; McILWRAITH, C. W. Técnicas Cirúrgicas em Animais de Grande Porte. l.ed. São Paulo: Roca, 2002. 341 p.

WATKINS, A.; PARENTE, E. J. Salpingopharyngeal fistula as a treatment for guttural pouch mycosis in 7 horses. Equine Veterinary Journal. v. 17, p.781-786, 2018. 